\title{
Variations in Erosion Risk in Western Anatolia (Turkey): Modified Fournier Approach
}

\author{
Ercan Yeşilırmak $^{1^{*}}$ (iD) Levent Atatanır $^{2}$ iD \\ ${ }^{1}$ Department of Biosystems Engineering, Faculty of Agriculture, Aydın Adnan Menderes University, Aydın, Turkey \\ ${ }^{2}$ Department of Soil Science and Plant Nutrition, Faculty of Agriculture, Aydın Adnan Menderes University, Aydın, Turkey \\ *Corresponding author: eyesilirmak@adu.edu.tr
}

Geliş Tarihi: 25.01.2021

Kabul Tarihi: 20.03.2021

\begin{abstract}
As a result of global warming, more intense rainfall events and hence higher flood and erosion risk are expected to occur more likely. As erosion has been an important environmental problem in Turkey, it would be beneficial to document how it changed during global warming era. The aim of this study is to investigate the temporal evoluation of erosion risk from 1950 to 2018 in western Anatolia (Turkey), by using Modified Fournier Index (MFI). Also, temporal patterns of annual average temperature and annual total rainfall were analysed. The results, firstly, showed that the study area has cooled slightly from 1950 to 1976 and strongly warmed afterwards $\left(-0.24\right.$ and $0.48{ }^{\circ} \mathrm{C}$ decade $^{-1}$ on average, respectively), which is consistent with the temporal pattern of global average temperature. Neither annual total rainfall nor MFI showed statistically significant tendencies during both periods. Erosion risk during the rapid warming period (average MFI $=116.7$ ) was not different from that in the cooling period (average MFI = 124.7). It follows that, on the contrary to the expectation, erosion risk in the study area stayed unchaged while average temperature increased substantially after mid-1970s.
\end{abstract}

Key words: Climate Change, Erosion, Flood, Temperature, Extreme Precipitation

\section{Batı Anadolu'da Erozyon Riskindeki Değişimler: Modifiye Fournier Yaklaşımı $\ddot{\mathbf{O}} \mathbf{z}$}

Küresel ısınmanın sonucu olarak, daha şiddetli yağışlar ve buna bağlı olarak taşkın ve erozyon riskinde artış beklenmektedir. Erozyonun Türkiye'nin en önemli çevre sorunlarından biri olması nedeniyle, küresel 1sınmayla birlikte erozyon riskinde nasıl bir değişim olduğunun ortaya konması yararlı bilgiler verebilir. $\mathrm{Bu}$ çalışmada, 1950 ile 2018 yılları arasında, batı Anadolu'da modifiye Fournier indeksi kullanılarak erozyon riskindeki değişimler incelenmiştir. Ayrıca, çalışma alanındaki yıllık ortalama sıcaklıklar ile yıllık toplam yağışlardaki değişimler de incelenmiştir. Sonuçlar, çalışma alanındaki yıllık ortalama sıcaklıkların, küresel sıcaklık değişimi ile uyumlu olarak, 1950 ile 1976 arasında hafif bir azalış ve ardından 1976 sonrasında ise hızlı bir artış eğiliminde olduğunu (ortalama olarak, sırasıyla, -0.24 and $0.48{ }^{\circ} \mathrm{C}$ ony1 $1^{-1}$ ), hem yıllık toplam yağışlarda hem de MFI değerlerinde her iki dönem içinde de istatistiksel olarak önemli bir değişim eğilimi olmadığını göstermiştir. Hızlı 1sınma dönemindeki erozyon riski (ortalama MFI = 116.7), hafif soğuma dönemindekinden (ortalama MFI = 124.7) farklı bulunmamıştır. Batı Anadolu'daki 1970'lerin ortasından itibaren gerçekleşen hızlı sıcaklık artışına rağmen, beklentinin aksine, erozyon riskinde bir değişim olmadığı saptanmıştır.

Anahtar Kelimeler: İklim Değişikliği, Erozyon, Taşkın, Sıcaklık, Ekstrem Yağış

\section{Introduction}

Erosion has long been considered as the most important environmental problem in Turkey. Land use, topography, soil type, vegetation and rainfall are the most important factors that cause erosion by water. Turkey has a mean elevation of $1250 \mathrm{~m}$, and more than $64 \%$ of its surface area has a slope greater than $12 \%$ (Parlak, 2014). About $12 \%$ of Turkey is under severe or very severe erosion risk. As a result of intensive measures, annual soil loss due to erosion has dropped from 500 million tons per year in 1970s to 154 million tons in 2017, and is projected to drop to 130 million tons in 2023 (Anonymous, 2020).

Estimation of soil loss due to erosion is crucial in terms of adopting proper land use planning and development strategies (Biswas and Pani, 2015). Among the various estimation methods, the Universal Soil Loss Equation (USLE) or revised USLE (RUSLE) are extensively used approaches. The USLE is given as 
where $\mathrm{A}$ is average annual soil loss $\left(\right.$ ton $\mathrm{ha}^{-1} \mathrm{year}^{-1}$ ) over the long term period, $\mathrm{R}$ is the rainfall-runoff "erosivity" factor, $\mathrm{K}$ is the soil "erodibility" factor, $\mathrm{L}$ and $\mathrm{S}$ are the topographic factors, $\mathrm{C}$ is the crop and crop management factor, and $\mathrm{P}$ is the soil conservation practice factor (Kinnell, 2010). $\mathrm{R}$ factor is considered as the most important component of the USLE (Amara et al., 2020), and determined by calculating the average annual sum of the product of a storm's kinetic energy (E) and its maximum 30min intensity (I30), known as the EI30 (Garcia-Marin et al., 2017). High-resolution rainfall data are required to calculate $\mathrm{R}$ values. However, such data are generally unavailable in required spatial and temporal coverage. Instead, alternative indices were developed and have been extensively used, which make use of daily, monthly or annual rainfall total. The index proposed by Fournier (1960) was shown to have a high correlation with the amount of sediment transported into stream by runoff (Munka et al., 2007). Fournier index (FI) is the squared monthly rainfall divided by annual rainfall total. Modified Fournier Index abbreviated as MFI is the total of all FI values within a year. Numerous researches made use of FI and/or MFI to explore the status and/or time variation of erosion risk, or to estimate R value in USLE/RUSLE models, for example in Rwanda (Muhire et al., 2015), in Spain (De Luis et al., 2010; Hernando and Romana, 2015; Garcia-Marin et al., 2017), in Italy (Di Lena et al., 2013; Capra et al., 2017), in Ethiopia (Meshesha et al., 2015), in Uruguay (Munka et al., 2007), in Portugal (Nunes et al., 2016), in Jordan (Eltaif et al., 2010), in Korea (Lee and Heo, 2011), in the Netherlands (Lukiç et al., 2018), in Turkey (Bayramin et al., 2006; İrvem et al., 2007; Yuksel et al., 2008; Imamoglu and Dengiz, 2017; Oğuz, 2019).

The earth has been experiencing a temperature increase since the late 19th century. With the warming, changes in extreme precipitation events are expected (Cubasch et al., 2013), due to the increase in water holding capacity of air as a result of increased air temperature (Fowler and Hennessy, 1995; Mishra and Singh, 2010), leading to more frequent and severe flood events (Li et al., 2011; Coscarelli and Caloiero 2012) and thereby a higher risk of erosion.

Previous studies have shown that Turkey, particularly western Anatolia, have experienced substantial warming for 30-40 years (Akçakaya et al., 2015). It would be crucial to ascertain how erosion risk has changed over that period; has it become more severe under increased air temperature as expected? The objective of this study is to answer that question using MFI for the period from 1950 to 2018. The results are expected be useful for soil conservation and/or water management strategies and for understanding regional effects of increased temperature.

\section{Materials and Methods}

The stations whose climatic data analysed in this study are located in western Anatolia, limited by Marmara Sea in the north, Aegean Sea in the west and Mediterranean Sea in the south (Figure 1). The stations are also listed in Table 1, together with their geographical attributes.

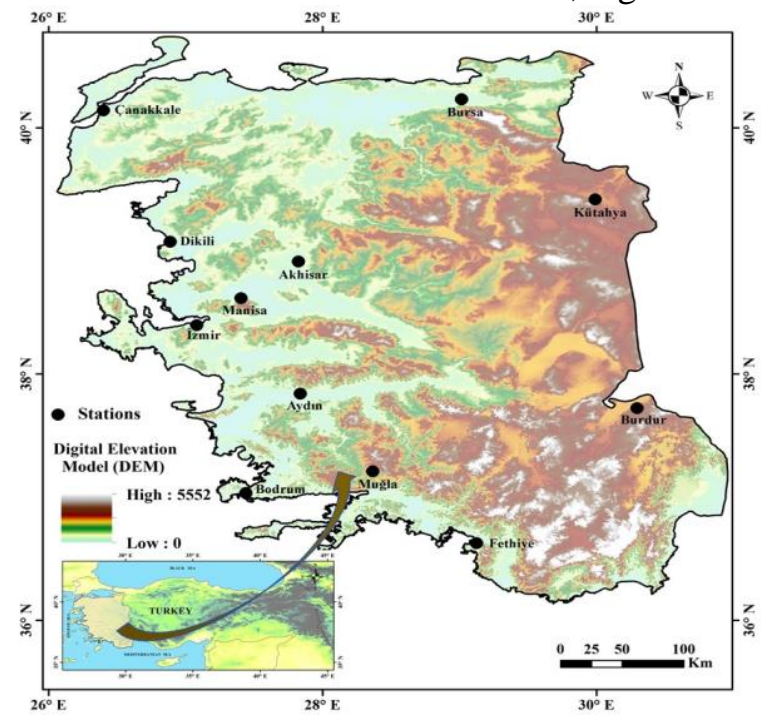

Figure 1. Locations of the stations within western Anatolia. 
Precipitation and temperature data were supplied from The State Meteorological Service of Turkey (MGM) for 12 weather stations in daily basis, which cover the period from 1950 to 2018 with minimum missing data and the longest period of record possible. The percentage of missing days at any station was less than $0.5 \%$. All of them were filled by averaging the values of the neighbouring days (Li et al., 2011). Daily values were summed or averaged to obtain firstly monthly, then seasonal and annual totals or averages. Each rainfall and temperature series were checked for consistency by the double-mass curve method (Zhang et al., 2012). The results revealed that all series were consistent.

Table 1. The list of the stations with their geographical attributes

\begin{tabular}{lcrr}
\hline Station & Latitude $\left({ }^{\circ} \mathrm{N}\right)$ & Longitude $\left({ }^{\circ} \mathrm{E}\right)$ & $\begin{array}{c}\text { Elevation } \\
(\mathrm{m} . \text { a.s.1.) }\end{array}$ \\
\hline Akhisar & 38.9118 & 27.8233 & 92 \\
Aydın & 37.8402 & 27.8379 & 56 \\
Bodrum & 37.0328 & 27.4398 & 26 \\
Burdur & 37.7220 & 30.2940 & 957 \\
Bursa & 40.2308 & 29.0133 & 100 \\
Çanakkale & 40.1410 & 26.3993 & 6 \\
Dikili & 39.0737 & 26.8880 & 3 \\
Fethiye & 36.6266 & 29.1238 & 3 \\
İzmir & 38.3949 & 27.0819 & 29 \\
Kütahya & 39.4171 & 29.9891 & 969 \\
Manisa & 38.6153 & 27.4049 & 71 \\
Muğla & 37.2095 & 28.3668 & 646 \\
\hline
\end{tabular}

Modified Fournier Index (MFI), which was originally proposed by Fournier (1960) and then modified by Arnoldus (1980) is calculated for each year as given below

$M F I=\sum_{i=1}^{12} \frac{p_{i}^{2}}{R}$

where $\mathrm{P}$ is the monthly rainfall total and $\mathrm{R}$ is the annual rainfall total. Based on index values, rainfall erosivity is classified as very low $(0<\mathrm{MFI}<60)$, low $(60<\mathrm{MFI}<90)$, moderate $(90<\mathrm{MFI}<120)$, high $(120<$ MFI < 160), and very high (MFI > 160) (Nunes et al., 2016).

Non-parametric Mann-Kendall test was employed to detect statistical significance of trends in each time series at each station by using the Excel template MAKESENS (Salmi et al., 2002). In Mann-Kendall test, the null hypothesis of no trend $\left(H_{0}\right)$ is that the observations $x_{i}$ are randomly ordered in time. Alternative hypothesis $\left(H_{1}\right)$ states that there exists an upward or downward monotonic trend. The test statistic $S$ is calculated as given below

$S=\sum_{k=1}^{n-1} \sum_{j=k+1}^{n} \operatorname{sgn}\left(x_{j}-x_{k}\right)$

where $x_{j}$ and $x_{k}$ are the values in year $j$ and $k$, respectively, and

$\operatorname{sgn}\left(x_{j}-x_{k}\right)=\left\{\begin{array}{c}1 \text { if } x_{j}-x_{k}>0 \\ 0 \text { if } x_{j}-x_{k}=0 \\ -1 \text { if } x_{j}-x_{k}<0\end{array}\right.$

If the number of data points is 9 or less, then the absolute value of $S$ is compared directly to the theoretical distribution of $S$ (Gilbert, 1987). The normal approximation test is used, If $n$ is at least 10. The variance of $S$ is estimated using the following equation which considers equal values, if any,

$\operatorname{VAR}(S)=1 / 18\left[n(n-1)(2 n+5)-\sum_{p=1}^{q} t_{p}\left(t_{p}-1\right)\left(2 t_{p}+5\right)\right]$ 
where $q$ is the number of tied groups and $t_{p}$ is the number of data values in the $p^{\text {th }}$ group. Then, the test statistic $Z$ is calculated using $S$ and $\operatorname{VAR}(S)$ as follows

$Z= \begin{cases}\frac{s-1}{\sqrt{\operatorname{VAR}(S)}} & \text { if } S>0 \\ 0 & \text { if } S=0 \\ \frac{s+1}{\sqrt{\operatorname{VAR}(S)}} & \text { if } S<0\end{cases}$

A positive (negative) value of $Z$ indicates an upward (downward) trend. The statistic $Z$ has a normal distribution. If there is a statistically significant monotonic trend (a two-tailed test) at $\alpha$ level of significance, $H_{0}$ is rejected if the absolute value of $Z$ is greater than $Z_{1-\alpha / 2}$ where $Z_{1-\alpha / 2}$ is obtained from the standard normal cumulative distribution tables. In this study, the significance level of $\alpha=0.05$ was used. The trend rates $(\beta)$ were determined using Sen's Slope Estimator:

$\beta=\operatorname{Median}\left(\frac{x_{i}-x_{j}}{i-j}\right), \forall j<i$

The statistical significance of changes in mean values of MFI between subperiods was evaluated using t-test (Munka et al., 2007).

\section{Results}

Firstly, temporal patterns of annual mean temperature series for all individual stations and regional mean averaged over all stations were investigated during whole period of 1950-2018. Figure 2 shows the temporal evolution of regional annual average temperature from 1950 to 2018 . There was a cooling tendency between 1950 and 1976 , with a rate of $0.24{ }^{\circ} \mathrm{C}$ decade ${ }^{-1}$ on average. The year 1976 was the coolest year, $15.1{ }^{\circ} \mathrm{C}$ on average, over the whole study period of 1950-2018. At individual stations, this cooling is statistically significant at $95 \%$ level at only three stations, namely Aydin, Burdur and Fethiye (Table 2). The highest rate of cooling was observed at Fethiye with a rate of -0.92 ${ }^{\circ} \mathrm{C}$ decade ${ }^{-1}$.

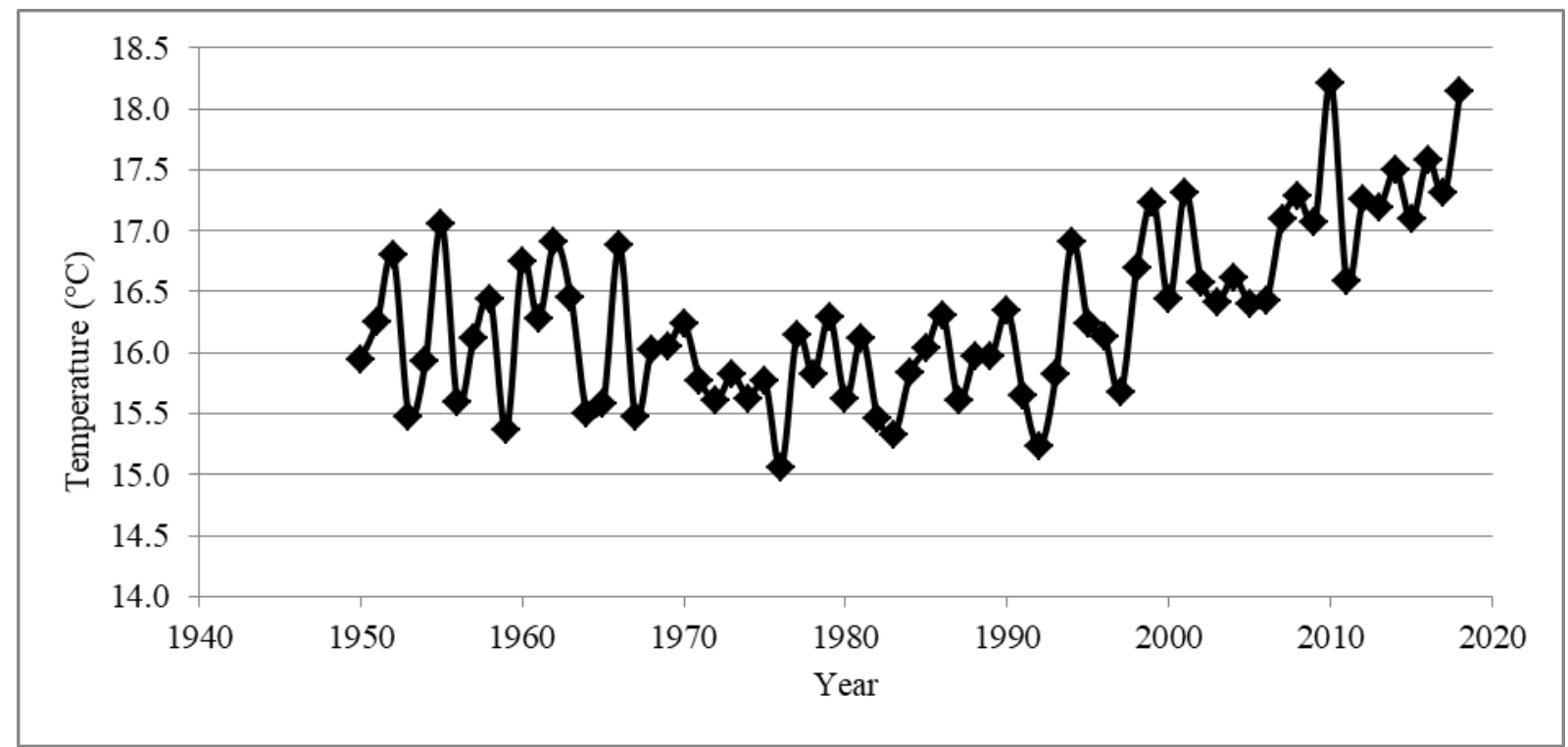

Figure 2. Temporal pattern of regional mean temperature over the study area

After the coolest year 1976, annual average temperature experienced a rapid increase. During this period, all stations had statistically significant increasing trends, ranging from $0.37{ }^{\circ} \mathrm{C}$ decade $^{-1}$ at İzmir to $0.77{ }^{\circ} \mathrm{C}$ decade ${ }^{-1}$ at Fehiye. Regional annual average trend was $0.48{ }^{\circ} \mathrm{C}$ decade ${ }^{-1}$. When seasonal average temperatures were analysed for trends during the same period, it was found that the 
trend rates were not homogeneous among seasons (Table 2). The rate of increase was the highest in summer and the lowest in winter at all stations, $0.071{ }^{\circ} \mathrm{C}$ year ${ }^{-1}$ and $0.029{ }^{\circ} \mathrm{C}$ year ${ }^{-1}$, respectively, in terms of regional averages. In other words, summer has warmed more than winter.

Table 2. Annual and seasonal average temperature trend rates $\left({ }^{\circ} \mathrm{C}_{\text {year }}{ }^{-1}\right)$ (Statistically significant trends at $95 \%$ shown in bold and red)

\begin{tabular}{lrrrrrr}
\hline \multirow{2}{*}{ Station } & \multicolumn{2}{c}{ Annual } & \multicolumn{3}{c}{ Seasonal (1976-2018) } \\
\cline { 2 - 7 } & $1950-1976$ & $1976-2018$ & Summer & Fall & Winter & Spring \\
\hline Akhisar & -0.022 & $\mathbf{0 . 0 5 2}$ & $\mathbf{0 . 0 8 0}$ & $\mathbf{0 . 0 5 2}$ & 0.020 & $\mathbf{0 . 0 5 7}$ \\
Aydın & $-\mathbf{0 . 0 4 5}$ & $\mathbf{0 . 0 4 9}$ & $\mathbf{0 . 0 6 9}$ & $\mathbf{0 . 0 4 5}$ & $\mathbf{0 . 0 2 7}$ & $\mathbf{0 . 0 4 6}$ \\
Bodrum & -0.008 & $\mathbf{0 . 0 5 4}$ & $\mathbf{0 . 0 7 8}$ & $\mathbf{0 . 0 5 3}$ & $\mathbf{0 . 0 3 9}$ & $\mathbf{0 . 0 5 2}$ \\
Burdur & $-\mathbf{0 . 0 4 3}$ & $\mathbf{0 . 0 3 9}$ & $\mathbf{0 . 0 6 2}$ & $\mathbf{0 . 0 3 2}$ & 0.021 & $\mathbf{0 . 0 4 6}$ \\
Bursa & -0.025 & $\mathbf{0 . 0 4 8}$ & $\mathbf{0 . 0 7 5}$ & $\mathbf{0 . 0 4 3}$ & 0.023 & $\mathbf{0 . 0 5 1}$ \\
Çanakkale & -0.021 & $\mathbf{0 . 0 4 8}$ & $\mathbf{0 . 0 7 2}$ & $\mathbf{0 . 0 4 9}$ & 0.030 & $\mathbf{0 . 0 5 0}$ \\
Dikili & -0.021 & $\mathbf{0 . 0 4 0}$ & $\mathbf{0 . 0 6 7}$ & $\mathbf{0 . 0 3 3}$ & 0.029 & $\mathbf{0 . 0 4 7}$ \\
Fethiye & $-\mathbf{0 . 0 9 2}$ & $\mathbf{0 . 0 7 7}$ & $\mathbf{0 . 1 1 3}$ & $\mathbf{0 . 0 7 5}$ & $\mathbf{0 . 0 4 8}$ & $\mathbf{0 . 0 7 2}$ \\
İzmir & -0.012 & $\mathbf{0 . 0 3 7}$ & $\mathbf{0 . 0 5 0}$ & $\mathbf{0 . 0 3 3}$ & 0.025 & $\mathbf{0 . 0 4 3}$ \\
Kütahya & -0.003 & $\mathbf{0 . 0 5 1}$ & $\mathbf{0 . 0 6 9}$ & $\mathbf{0 . 0 4 4}$ & $\mathbf{0 . 0 3 9}$ & $\mathbf{0 . 0 5 0}$ \\
Manisa & -0.012 & $\mathbf{0 . 0 4 2}$ & $\mathbf{0 . 0 5 9}$ & $\mathbf{0 . 0 4 1}$ & 0.017 & $\mathbf{0 . 0 4 8}$ \\
Muğla & -0.023 & $\mathbf{0 . 0 4 1}$ & $\mathbf{0 . 0 5 9}$ & $\mathbf{0 . 0 3 1}$ & $\mathbf{0 . 0 2 7}$ & $\mathbf{0 . 0 4 2}$ \\
Average & -0.024 & 0.048 & 0.071 & 0.044 & 0.029 & 0.050 \\
\hline
\end{tabular}

Annual total rainfall experienced non-significant trends at all stations during both periods of 1950-1976 and 1976-2018, except Bursa between 1976 and 2018 (Table 3). Annual total rainfall increased at Bursa with a rate of $34 \mathrm{~mm} \mathrm{decade}^{-1}$ during 1976-2018. Regionally, there were slight decrease and increase with the rates of $-13 \mathrm{~mm} \mathrm{decade}^{-1}$ and $14 \mathrm{~mm}$ decade $^{-1}$, respectively.

There has been an apparent seasonality in rainfall distribution among seasons (Table 3). A significant portion of total annual rainfall drops during winter. Winter rainfall contribution is as high as $59.0 \%$ at Bodrum. Its regional average is $48.6 \%$. Summer is the season in which the lowest amount of rainfall occurs. Summer rainfall contribution reaches the highest percentage (13.2\%) at Kütahya. It is less than $1 \%$ at Bodrum and Fethiye. In terms of regional average, about $5.1 \%$ total annual rainfall falls in summer.

Table 3. Trends in annual total rainfall (statistically significant trends at 95\% shown in bold and red) and the percentage of seasonal rainfall within annual rainfall

\begin{tabular}{lrrrrrr}
\hline \multirow{2}{*}{\multicolumn{1}{c}{ Station }} & \multicolumn{2}{c}{$\begin{array}{c}\text { Annual Total Rainfall Trend }(\mathrm{mm} \\
\text { year }{ }^{-1} \text { ) }\end{array}$} & \multicolumn{3}{c}{ Rainfall Percentage (\%) } \\
\cline { 2 - 7 } & $1950-1976$ & $1976-2018$ & Summer & Fall & Winter & Spring \\
\hline Akhisar & -1.9 & -0.6 & 4.0 & 22.1 & 47.9 & 26.0 \\
Aydın & -5.2 & 1.4 & 3.1 & 21.8 & 50.1 & 25.0 \\
Bodrum & -5.9 & 1.5 & 0.7 & 22.6 & 59.0 & 17.7 \\
Burdur & -2.7 & 0.4 & 11.7 & 20.2 & 36.5 & 31.6 \\
Bursa & 3.1 & 3.4 & 9.4 & 26.5 & 38.3 & 25.8 \\
Çanakkale & -2.9 & 2.4 & 6.5 & 26.9 & 43.6 & 23.0 \\
Dikili & -2.6 & 0.7 & 2.3 & 23.6 & 51.9 & 22.2 \\
Fethiye & -5.1 & 1.3 & 0.8 & 23.4 & 58.1 & 17.7 \\
İzmir & 1.4 & 0.6 & 2.0 & 22.3 & 53.6 & 22.1 \\
Kütahya & 3.7 & 1.3 & 13.2 & 20.3 & 36.8 & 29.7 \\
Manisa & 3.4 & -0.5 & 4.1 & 21.4 & 50.5 & 24.0 \\
Muğla & 1.1 & 1.2 & 3.6 & 19.3 & 56.8 & 20.3 \\
Average & -1.3 & 1.4 & 5.1 & 22.5 & 48.6 & 23.8 \\
\hline
\end{tabular}

Average MFI values at individuval stations during the periods 1950-1976 and 1976-2018, and the corresponding MFI classes are shown in Table 4. During the first period, MFI changed from 59.4 
(Burdur) to 228.9 (Muğla). While six stations had either "high" or "very high" risk of erosion, three stations had either "low" or "very low". Only three stations had "moderate" erosity. During the next period (1976-2018), MFI ranged from 60.2 (Burdur) to 205.3 (Muğla). In terms of erosion risk, five stations had "high" or "very high", and only two stations "low" erosion risk. Muğla and Fethiye located in South-western part of the sudy area are caharacterized as the locations with highest ersosion risk during both periods.

Table 4 shows also the changes in average MFI from the period 1950-1976 to the period 19762018 , together with corresponding risk classes, not only at individual stations but also in regional average. There were an overall slight decrease (5.2\%) in regionally averaged MFI, from 124.7 (high) to 116.7 (moderate).

Table 4. Average values, classes, and chages in MFI during two periods (statistically significant changes at $95 \%$ in average MFI shown in bold and red

\begin{tabular}{|c|c|c|c|c|c|c|}
\hline \multirow{2}{*}{ Station } & \multicolumn{2}{|c|}{$1950-1976$} & \multicolumn{2}{|c|}{$1976-2018$} & \multicolumn{2}{|c|}{ Change in MFI } \\
\hline & Average & Class & Average & Class & Absolute & Relative (\%) \\
\hline Akhisar & 103.0 & Moderate & 95.3 & Moderate & -7.7 & -7.5 \\
\hline Aydın & 107.8 & Moderate & 110.0 & Moderate & 2.2 & 2.0 \\
\hline Bodrum & 148.2 & High & 138.2 & High & -10.0 & -6.7 \\
\hline Burdur & 59.4 & Very low & 60.2 & Low & 0.8 & 1.3 \\
\hline Bursa & 89.4 & Low & 93.0 & Moderate & 3.6 & 4.0 \\
\hline Çanakkale & 105.4 & Moderate & 98.3 & Moderate & -7.1 & -6.7 \\
\hline Dikili & 133.2 & High & 105.4 & Moderate & -27.8 & -20.9 \\
\hline Fethiye & 186.2 & Very high & 167.1 & Very high & -19.1 & -10.3 \\
\hline İzmir & 127.8 & High & 131.3 & High & 3.5 & 2.7 \\
\hline Kütahya & 76.0 & Low & 72.6 & Low & -3.4 & -4.5 \\
\hline Manisa & 130.7 & High & 123.7 & High & -7.0 & -5.4 \\
\hline Muğla & 228.9 & Very high & 205.3 & Very high & -23.6 & -10.3 \\
\hline Average & 124.7 & High & 116.7 & Moderate & -8.0 & -5.2 \\
\hline
\end{tabular}

At individual stations, while eight stations had lower MFI during next period than perivous one, four stations had higher MFI. Increases seems to be minuscule compared to decreases. While increases ranged from $1.3 \%$ to $4 \%$, decreases varied from $5.4 \%$ to $20.9 \%$, which maked regionally averaged MFI decreasing. The only statistically significant change was observed at Dikili where MFI decreased from 133.2 (high) to 105.4 (moderate), corresponding to $20.9 \%$ decline. The classes stayed unchanged at nine stations. But, it shifted from "very low" to "low", from "low" to "moderate" and from "high" to "moderate" at other three stations (Table 4).

Temporal trends of MFI values during the periods 1950-1976 and 1976-2018 are presented in Table 5. In terms of regional averages, there were slight decreasing tendency between 1950 and 1976 and slight increasing tendency from 1976 to 2018. At individuval stations, the only statistically significant trend occurred at Bursa with a rate of 0.396 year $^{-1}$, equivalent to 17.0 increase in MFI value during 1976-2018. Other stations showed non-significant trends during both periods.

Table 6 displays the association between some geographic variables (latitude, longitude and elevation) and spatial and temporal variations of MFI and rainfall. Latitude has an inverse statistically significant correlation with MFI during both periods $(\mathrm{r}=-0.59$ and $\mathrm{r}=-0.61$, respectively). Latitude has also negative but non-significant correlation with annual rainfall. However, latitude has a positive (non-signficant) influence on spatial and temporal variations of MFI and rainfall during both periods, with $r$ values ranging from 0.31 to 0.53 . On the other hand, neither longitude nor elevation has an influence on MFI and rainfal in spatial and temporal domains. 
Table 5. MFI trend rates during two periods (statistically significant trends at 95\% shown in bold and red)

\begin{tabular}{lrr}
\hline \multirow{2}{*}{ Station } & \multicolumn{2}{c}{ MFI Trend (year ${ }^{-1}$ ) } \\
\cline { 2 - 3 } & $1950-1976$ & $1976-2018$ \\
\hline Akhisar & -0.841 & -0.184 \\
Aydın & -1.195 & 0.233 \\
Bodrum & -2.402 & 0.351 \\
Burdur & -0.671 & 0.041 \\
Bursa & -0.252 & $\mathbf{0 . 3 9 6}$ \\
Çanakkale & -0.936 & 0.509 \\
Dikili & -0.867 & 0.174 \\
Fethiye & -1.868 & -0.056 \\
İzmir & 0.133 & 0.069 \\
Kütahya & 0.237 & -0.065 \\
Manisa & -0.009 & -0.234 \\
Muğla & -0.296 & -0.253 \\
Average & -0.747 & 0.082 \\
\hline
\end{tabular}

Table 6. Correlations between mean values and trends of MFI and rainfall and some geographical attributes (statistically significant correlations at $95 \%$ shown in bold and red)

\begin{tabular}{lcccccccc}
\hline & \multicolumn{4}{c}{ Mean values } & \multicolumn{3}{c}{ MFI } & \multicolumn{2}{c}{ Annual Rainfall } \\
\cline { 2 - 9 } & \multicolumn{3}{c}{ MFI } & \multicolumn{3}{c}{ Annual Rainfall } & \multicolumn{3}{c}{ Ands } \\
\cline { 2 - 10 } & $1950-1976$ & $1976-2018$ & $1950-1976$ & $1976-2018$ & $1950-1976$ & $1976-2018$ & $1950-1976$ & $1976-2018$ \\
\hline Latitude & $\mathbf{- 0 . 5 9}$ & $-\mathbf{0 . 6 1}$ & -0.45 & -0.42 & 0.53 & 0.38 & 0.51 & 0.31 \\
Longitude & -0.26 & -0.25 & -014 & -0.11 & 0.16 & -0.31 & 0.20 & 0.08 \\
Elevation & -0.24 & -0.26 & -0.13 & -0.10 & 0.41 & -0.37 & 0.34 & -0.09 \\
\hline
\end{tabular}

\section{Discussion}

One of the expected consequences of global warming is the more intense rainfall events and hence a higher risk of erosion. Observations showed that global average temperature increase has not been temporally homogeneous. Whole period of increase since late 19th centruy includes cooling and warming subperiods. Global average temperature showed a small negative trend from 1940s to 1970s (Kosaka and Xie, 2016). This cooling is estimated to be $-0.04{ }^{\circ} \mathrm{C}$ decade ${ }^{-1}$ from 1941 to 1971 (Meehl, 2015). The results of this study showed that western Anatolia also experienced a slight cooling tendency from 1950 to 1976 at a rate of $-0.24{ }^{\circ} \mathrm{C}$ decade $^{-1}$ in terms of regional average, with most of stations exhibiting non significant decreasing trend. Over the same period, annual total rainfall and MFI at individual stations also had slighltly (statistically nonsignificant) decreasing trends. It follows that the results are in comply with the expectation that the slight cooling was accompanied by unchanged erosion risk.

The next period (1976-2018) is completely different from previous one (1950-1976) in terms of temperature evolution. During 1976-2018, annual average temperature increased substantially; all stations experienced strong temperature increase. However, MFI did not follow the same pattern. Instead, it stayed unchanged, even slightly decreased, which suggests that erosion risk slightly diminished or remained stable over the study area. This is not what is expected in that increased temperature may leads to more intense rainfall events due to increased water vapour holding capacity of air, and, in turn, may cause more severe erosion. One of the explanations for the contradiction would be the asymetrical temperature increases among seasons in the study area. While summer season has the strongest temperature increase, it receives the smallest portion of annual total rainfall. Conversely, winter receives the highest portion but experiences the lowest temperature increase. It should be also noted that extreme precipitation events in western Anatolia, also in Turkey and eastern Mediterranean, are controlled by various ocean-atmosphere teleconnection patterns such as North Atalantic Oscillation (NAO), Arctic Oscillation (AO), El Nino Southern Oscillation (ENSO) and East Atlantic/Western Russian (EA/WR) pattern (Krichak et al., 2014; Duzenli et al., 2018). 
Significant correlations between latitude and MFI during both periods suggest that the stations with higher latitudes have lower risk of erosion than those with lower latitudes. Similarly, weaker (and, also non-significant) inverse correlations between latitude and rainfall imply a similar pattern, i.e., a decreasing rainfall from the South to the North. This can be attributed to the weaking of moisture-rich air masses from Mediterranean sea toward North. Elevation is a likely factor on rainfall and erosion risk, and improves the estimates of erosion risk mapping when incorparated into various interpolation techniques such as spline (e.g., Apaydın et al., 2006), kriging (e.g., Sanchez-Moreno et al., 2014). Various studies reported strong agreements between erosion and elevation or other geographical variables such as latitude and longitude (e.g., Jiang et al., 2012; Zhou et al., 2014; Ochoa-Cueva et al., 2015; İkiel et al., 2020). No such a relationship was found between elevation and erosion risk in this study, possibly due to the limited number of stations. As the objective in this study was to analyse the erosion risk, quantified by MFI, particularly in temporal domain under so-called global warming, the main criterion was to select the stations with temperature and rainfall series as long as possible in such a way that they should cover the globally observed slight cooling period within the third quarter of 20 th century. Among the numerous stations, the selection process, including consistency, resulted in only twelve stations in the study area, which may not be sufficient to validate/invalidate that relationship.

A number of previous studies are in good agreement with the results of this study. For example, Abbasnia and Toros (2020), Ağbaş (2019), Yeşilırmak and Atatanır (2016), Sensoy et al. (2013) detected no statistically significant changes in extreme precipitation events in western Anatolia, which suggest no change in erosion risk. As less data requirement and easily applicability have made MFI an extensively used tool to evaluate temporal evolution of erosion risk throught the World. Some of them are as follows: no overall trend over eastern Africa during 1981-2016 (Fenta et al., 2017) and in Portugal during 1950-2008 (Nunes et al., 2016), both increasing and decreasing trends in Mediterranean Iberian Peninsula during 1951-2000 (De Luis et al., 2010) and in the Netherlands during 1957-2016 (Lukiç et al., 2018), mostly increasing trends in Bangladesh during 1981-2010 (Alam and Sarker, 2014), mostly decreasing trends in the Abruzzo Region of Italy during 1951-2009 (Di Lena et al., 2013). According to these results, there have been no coherency on the direction and strength of trends. This can be attributed to the spatial inhomogeneity of global warming, regional or local geographical factors, data period used, internal atmospheric variability etc., which need further research.

\section{Conclusions}

This study shows that western Anatolia (Turkey) has not undergone a significant tendency in erosion risk, quantified by MFI, during rapid warming period from 1976 to 2018. In other words, warmed air temperature has not been accompanied by higher erosion risk during that period. This does not comply with the expectation that warmer air leads to higher erosion, by creating more intense rainfall events. Besides, erosion risk during rapid warming period was not significantly different from that of slight cooling period. It seems that warmed air does not necessarily lead to a higher erosion risk. Some other factors such as atmospheric circulation patterns, local/regional geography etc. may involve, which should be taken into account in soil coservation and water management strategies.

Land use, topography, soil type, vegetation and rainfall are influential on erosion by water. It should be stressed that this study focused solely on rainfall, to answer the question how the effect of rainfall on erosion risk changed as a result of warmed air temperature since more intense rainfall events and hence higher risk of erosion are expected due to global warming. All other factors that cause erosion were assumed to have stayed unchanged. However, they may have been altered, and actual soil loss may have changed particularly due to the changes in land use and vegatation, even diminished as a result of preventive measures.

The simple and straightforward approach used in this study is generally considered as very useful tool particularly for regions and times in which high temporal resolution rainfall records are unavailable. Growing number of automated weather stations within last one or two decades in Turkey provide high resolution rainfall records, and enable more sophisticated tools/approaches to be used more extensively for more accurate estimations of status and trends of soil loss. 


\section{References}

Abbasnia, M., Toros, H., 2020. Trend analysis of weather extremes across the coastal and non-coastal areas (case study: Turkey). J. Earth Syst. Sci. 129: 95.

Ağbaş, İ., 2019. Batı Anadolu'da günlük yağış şiddetindeki değişimler. Aydın Adnan Menderes Üniversitesi, Fen Bilimleri Enstitüsü, Tarımsal Yapılar ve Sulama Anabilim Dalı, Yüksek Lisans Tezi. 135 s.

Akçakaya, A., Sümer, U.M., Demircan, M., Demir, Ö., Atay, H., Eskioğlu, O., Gürkan, H., Yazıcı, B., Kocatürk, A., Şensoy, S., Bölük, E., Arabacı, H., Açar, Y., Ekici, M., Yağan, S., Çukurçayır, F., 2015. Yeni senaryolar ile Türkiye İklim Projeksiyonları ve İklim Değiş̧ikliği. Meteoroloji Genel Müdürlüğü, Ankara.

Alam, M.D.T., Sarker, T., 2014. Precipitation distribution and erosivity in Bangladesh: 1981-2010. European Academic Research. 1: 5167-5177.

Amara, D.M.K., Ullah, K., Yushu, Z., 2020. Rainfall erosivity estimation for Sierra Leone using non-parametric indices. Theor. Appl. Climatol. 139: 221-236.

Anonymous, 2020. Türkiye'de Erozyon. TC Tarım ve Orman Bakanlığı, Çölleşme ve Erozyonla Mücadele Genel Müdürlüğü. https://www.tarimorman.gov.tr/CEM/Menu/39/Belgeler.

Apaydin, H., Erpul, G., Bayramin, I., Gabriels, D., 2006. Evaluation of indices for characterizing the distribution and concentration of precipitation: A case for the region of Southeastern Anatolia Project, Turkey. J. Hydrol. 328: 726- 732.

Arnoldus, H.M.J., 1980. An approximation of the rainfall factor in the Universal Soil Loss Equation. In: De Boodt, M. and Gabriels D. (eds.). Assessment of soil erosion. John Wiley and Sons, Chichester, Gran Bretaña. p. 127-132.

Bayramin, İ., Erpul, G., Erdoğan, H.E., 2006. Use of CORINE methodology to assess soil erosion risk in the semi-arid area of Beypazar1, Ankara. Turk. J. Agric. For. 30: 81-100.

Biswas, S.S., Pani, P., 2015. Estimation of soil erosion using RUSLE and GIS techniques: a case study of Barakar River basin, Jharkhand, India. Mod. Ear. Syst. Environ. 1: 42.

Capra, A., Porto, P., La Spada, C., 2017. Long-term variation of rainfall erosivity in Calabria (Southern Italy). Theor. Appl. Climatol. 128:141-158.

Coscarelli, R., Caloiero, T., 2012. Analysis of daily and monthly rainfall concentration in Southern Italy (Calabria region). J. Hydrol. 416-417: 145-156.

Cubasch, U., Wuebbles, D., Chen, D., Facchini, M.C., Frame, D., Mahowald, N., Winther, J.G., 2013. Introduction. In: Stocker, T.F., Qin, D., Plattner, G.K., Tignor, M., Allen, S.K., Boschung, J., Nauels, A., Xia, Y., Bex, V., Midgley, P.M. (eds) Climate Change 2013: The Physical Science Basis. Contribution of Working Group I to the Fifth Assessment Report of the Intergovernmental Panel on Climate Change. Cambridge University Press, Cambridge.

De Luis, M., Gonzales-Hidalgo, J.C., Longares, L.A., 2010. Is rainfall erosivity increasing in the Mediterranean Iberian Peninsula? Land Degrad. Dev. 21: 139-144.

Di Lena, B., Antenucci, F., Vergni, L., Mariani, L., 2013. Analysis of the climatic aggressiveness of rainfall in the Abruzzo region. Ital. J. Agrometeorol. 1: 33-44.

Duzenli, E., Tabari, H., Willems, P., Yilmaz, M.T., 2018. Decadal variability analysis of extreme precipitation in Turkey and its relationship with teleconnection patterns. Hydrol. Process. 32: 3513-3528.

Eltaif, N.I., Gharaibeh, M.A., Al-Zaitawi, F., Alhamad, M.N., 2010. Approximation of rainfall erosivity factors in North Jordan. Pedosphere 20: 711-717.

Fenta, A.A., Yasuda, H., Shimizu, K., Haregeweyn, N., Kawai, T., Sultan, D., Ebabu, K., 2017. Spatial distribution and temporal trends of rainfall and erosivity in the Eastern Africa region. Hydrol. Process. 31: 4555-4567.

Fournier, F., 1960. Climat et érosion: la relation entre l'érosion du sol par l'eau et les précipitations atmosphériques. Paris: Presses Universitaires de France.

Fowler, A.M., Hennessy, K.J., 1995. Potential impacts of global warming on the frequency and magnitude of heavy precipitation. Nat. Hazards 11: 283-303.

García-Marín, A.P., Ayuso-Muñoz, J.L., Cantero, F.N., Ayuso-Ruiz, J.L., 2017. Spatial and trend analyses of rainfall seasonality and erosivity in the West of Andalusia (Period 1945-2005). Soil Sci. 182: 146-158.

Gilbert, R.O., 1987. Statistical methods for environmental pollution monitoring. Van Nostrand Reinhold Company, New York.

Hernando, D., Romana, M.G., 2015. Estimating the rainfall erosivity factor from monthly precipitation data in the Madrid Region (Spain). J. Hydrol. Hydromech. 63: 55-62.

Imamoglu, A., Dengiz, O., 2017. Determination of soil erosion risk using RUSLE model and soil organic carbon loss in Alaca catchment (Central Black Sea region, Turkey). Rend. Fis. Acc. Lincei 28: 11-23.

İkiel, C., Ustaoğlu, B., Koç, D.E., 2020. Trakya Yarımadası'nda erozyon duyarlılık analizi. Jeomorfolojik Araştırmalar Dergisi. 2020 (4): 1-14 
İrvem, A., Topaloğlu, F., Uygur, V., 2007. Estimating spatial distribution of soil loss over Seyhan River Basin in Turkey. J. Hydrol. 336: 30- 37.

Jiang, Z., Su, S., Jing, C., Lin, S., Fei, X., Wu, J., 2012. Spatiotemporal dynamics of soil erosion risk for Anji County, China. Stoch. Environ. Res. Risk. Assess. 26: 751-763.

Kinnell, P.I.A., 2010. Event soil loss, runoff and the Universal Soil Loss Equation family of models: A review. J. Hydrol. 385: 384-397.

Kosaka, Y., Xie, S.P., 2016. The tropical Pacific as a key pacemaker of the variable rates of global warming. Nat. Geosci. 9: 669-673.

Krichak, S.O., Breitgand, J.S., Gualdi, S., Feldstein, S.B., 2014. Teleconnection-extreme precipitation relationships over the Mediterranean region. Theor. Appl. Climatol. 117: 679-692.

Lee, J.H., Heo, J.H., 2011. Evaluation of estimation methods for rainfall erosivity based on annual precipitation in Korea. J. Hydrol. 409: 30-48.

Li, X., Jiang, F., Li, L., Wang, G., 2011. Spatial and temporal variability of precipitation concentration index, concentration degree and concentration period in Xinjiang, China. Int. J. Climatol. 31: 1679-1693.

Lukić, T., Basarin, B., Micić, T., Bjelajac, D., Maris, T., Marković, S.B., Pavić, D., Gavrilov, M.B., Mesaroš, M., 2018. Rainfall erosivity and extreme precipitation in the Netherlands. IDOJARAS Quarterly Journal of the Hungarian Meteorological Service. 122: 409-432.

Meehl, G.A., 2015. Decadal climate variability and the early-2000s hiatus. US Clivar Variations. 13(3): 1-6.

Meshesha, D.T., Tsunekawa, A., Tsubo, M., Haregeweyn, N., Adgo, E., 2015. Evaluating spatial and temporal variations of rainfall erosivity, case of Central Rift Valley of Ethiopia. Theor. Appl. Climatol. 119:515522.

Mishra, A.K., Singh, V.P., 2010. Changes in extreme precipitation in Texas. J. Geophys. Res-Atmos. 115:D14106.

Muhire, I., Ahmed, F., Abd Elbasit, M.M.M., 2015. Spatio-temporal variations of rainfall erosivity in Rwanda. Journal of Soil Science and Environmental Management. 6: 72-83.

Munka, C., Cruz, G., Caffera, R.M., 2007. Long term variation in rainfall erosivity in Uruguay: a preliminary Fournier approach. GeoJournal. 70: 257-262.

Nunes, A.N., Lourenço, L., Vieira, A., Bento-Gonçalves, A., 2016. Precipitation and erosivity in southern Portugal: seasonal variability and trends (1950-2008) Land Degrad. Dev. 27: 211-222.

Ochoa-Cueva, P., Fries, A., Montesinos, P., Rodriguez-Diaz, J.A., Boll, J., 2015. Spatial estimation of soil erosion risk by land-cover change in the Andes of southern Ecuador. Land Degrad. Dev. 26: 565-573.

Oğuz, I., 2019. Rainfall erosivity in north-central Anatolia in Turkey. Appl. Ecol. Env. Res. 17: 2719-2731.

Parlak, M., 2014. Çanakkale-Lapseki'de farklı arazi kullanım şekillerinin sıçrama erozyonuna etkileri. ÇOMÜ Zir. Fak. Derg. 2: 67-72.

Salmi, T., Maata, A., Antilla, P., Ruoho-Airola, T., Amnell, T., 2002. Detecting trends of annual values of atmospheric pollutants by the Mann-Kendall test and Sen's slope estimates - the Excel template application Makesens. Finnish Meteorological Institute, Helsinki.

Sanchez-Moreno, J.F., Mannaerts, C.M., Jetten V. 2014. Rainfall erosivity mapping for Santiago Island, Cape Verde. Geoderma. 217-218: 74-82.

Sensoy, S., Turkoglu, N., Akçakaya, A., Ekici, M., Demircan, M., Ulupınar, Y., Atay, H., Tüvan, A., Demirbaş, H., 2013. Trends in Turkey climate indices from 1960 to 2010. 6th Atmospheric Science Symposium, 2426 April, Istanbul, Turkey.

Yeşilırmak, E., Atatanır, L., 2016. Spatiotemporal variability of precipitation concentration in western Turkey. Nat. Hazards 81: 687-704.

Yuksel, A., Gundogan, R., Akay, A.E., 2008. Using the remote sensing and GIS technology for erosion risk mapping of Kartalkaya dam watershed in Kahramanmaras, Turkey. Sensors. 8: 4851-4865.

Zhang, Q., Zhou, Y., Singh, V.P., Li, J., 2012. Scaling and clustering effects of extreme precipitation distributions. J. Hydrol. 454-455: 187-194.

Zhou, Q., Yang, S., Cai, M., Lu, Y., Zhao, H.G., Luo Y., 2014. Soil erosion and its relationship with topographical factors in a mountainous watershed in the upper Mekong river in Yunnan province, China. Fresen. Environ. Bull. 23: 219-226. 